\title{
Маски синдрому мальперфузії при гострому розшаруванні аорти типу В (клінічний випадок)
}

\author{
Ящук Н. С., Дітківський І. О., Черпак Б. В., Кравченко В. І., Лазоришинець В. В. \\ ДУ «Національний інститут серцево-судинної хірургії імені М. М. Амосова НАМН України», м. Київ, Україна
}

\begin{abstract}
Резюме. Синдром мальперфузії відзначається приблизно у третини хворих із гострим розшаруванням аорти типу В і $є$ незалежним фактором ризику внутрішньогоспітальної летальності, яка, згідно з даними IRAD (міжнародного реєстру розшарувань аорти), становить 30,8\%. Варіабельність симптомів при синдромі мальперфузії значна: у 28\% пацієнтів із симптомами «гострого живота», за даними вказаного реєстру, наявна затримка у встановленні діагнозу, що і зумовлює прогресування захворювання і високі цифри летальності. У цій статті ми представляємо випадок успішного лікування динамічної мальперфузії вісцеральних органів із затримкою у два тижні, прихованої за маскою гострого панкреатиту.
\end{abstract}

Ключові слова: синдром мальперфузї, гостре розшарування аорти, гострий панкреатит.

Гостре розшарування аорти типу В відносять також до гострого аортального синдрому (acute aortic syndrome) - невідкладного стану, оскільки воно може призвести до мальперфузії (різкого зниження кровопостачання) вісцеральних органів, нирок, спинного мозку та нижніх кінцівок. Смертність від гострого розшарування аорти, ускладненого синдромом мальперфузії, за різними джерелами, сягає від 25 до 62\% [5-7]. Згідно з даними IRAD (International Registry of Aortic Dissection), раннє хірургічне або інтервенційне втручання дозволяє знизити летальність у пацієнтів із синдромом мальперфузії з 62 до 25\% [1, 6, 7]. Вірогідність синдрому мальперфузії у пацієнтів із гострим розшаруванням становить $21 \%$ (IRAD), серед них мезентеріальна ішемія трапляється з частотою 5,3\%, ниркова недостатність - 13,5\%, ішемія нижніх кінцівок $-7,1 \%$. При цьому серед пацієнтів міжнародного реєстру не зареєстровано жодного випадку гострого панкреатиту на фоні мальперфузії truncus celiacus та селезінкової артерії. Ми представляємо випадок синдрому мальперфузії вісцеральних органів з розвитком гострого ішемічного панкреатиту, вірогідною причиною якого було гостре розшарування аорти типу В.

Матеріали і методи. Чоловік, 62 роки, 110 кг, поступив до обласної лікарні зі скаргами на різкий біль у животі, що віддавав у спину. Напередодні вживав алкоголь і жирну їжу. В анамнезі гіпертонічна хвороба III стадії, цукровий діабет II типу. Об'єктивно: живіт здутий, напружений, симптоми подразнення очеревини сумнівні. Лабораторно: дещо підвищений рівень амілази крові: при поступленні 50 ОД/л з підвищенням до 120 Од/л через 12 годин. На УЗД органів черевної порожнини: ознаки хронічного калькульозного холециститу, жовчні протоки прохідні, підшлун- кова залоза збільшена, із зонами гіпоехогенності. Розпочато консервативну терапію: голод, інфузійна терапія, антибіотикотерапія та інгібітори протеаз. У динаміці через два тижні - розлитий біль у животі зберігається, живіт значно здутий, перистальтика не вислуховується, анурія з підвищенням рівня креатиніну до 596 ммоль/л, рівень амілази крові підвищився до 196 Од/л. 3 метою виключення панкреонекрозу пацієнту виконана комп'ютерна томографія з контрастуванням. За даними комп'ютерної томографії виявлено розшарування аорти типу В, усі вісцеральні судини відходять від істинного каналу, розмір істинного каналу на рівні відходження вісцеральних судин до 1 мм (рисунок 1, 2). Вираженість гострого панкреатиту 0 , гострий панкреатит легкого ступеня згідно 3 Японською КТ-шкалою.

Пацієнта переведено в інститут серцево-судинної хірургії. Розпочато консервативну терапію. Артеріальний тиск, незважаючи на введення метопрололу 5 мг та ебрантилу 50 мг залишався на рівні 140/90 мм рт. ст. Пацієнта в день госпіталізації виконано каротиднопідключичне шунтування з метою подовження зони посадки ендопротезу з подальшим ендопротезуванням аорти стент-графтом Ankura TAA stent-graft system. На контрольній ангіографії спостерігалося добре заповнення всіх вісцеральних судин (рисунок 3,4$)$. На наступний день після процедури спостерігалося відновлення діурезу. Живіт залишався здутим і болючим при пальпації, перистальтика не вислуховувалася. Враховуючи, що з моменту початку симптоматики мальперфузії вісцеральних органів минуло понад 2 тижні і що в 14-53\% пацієнтів розвивається некроз кишечника [2, 3], незважаючи на своєчасну гемодинамічну корекцію мальперфузії, пацієнту виконано діагностичну лапа- 

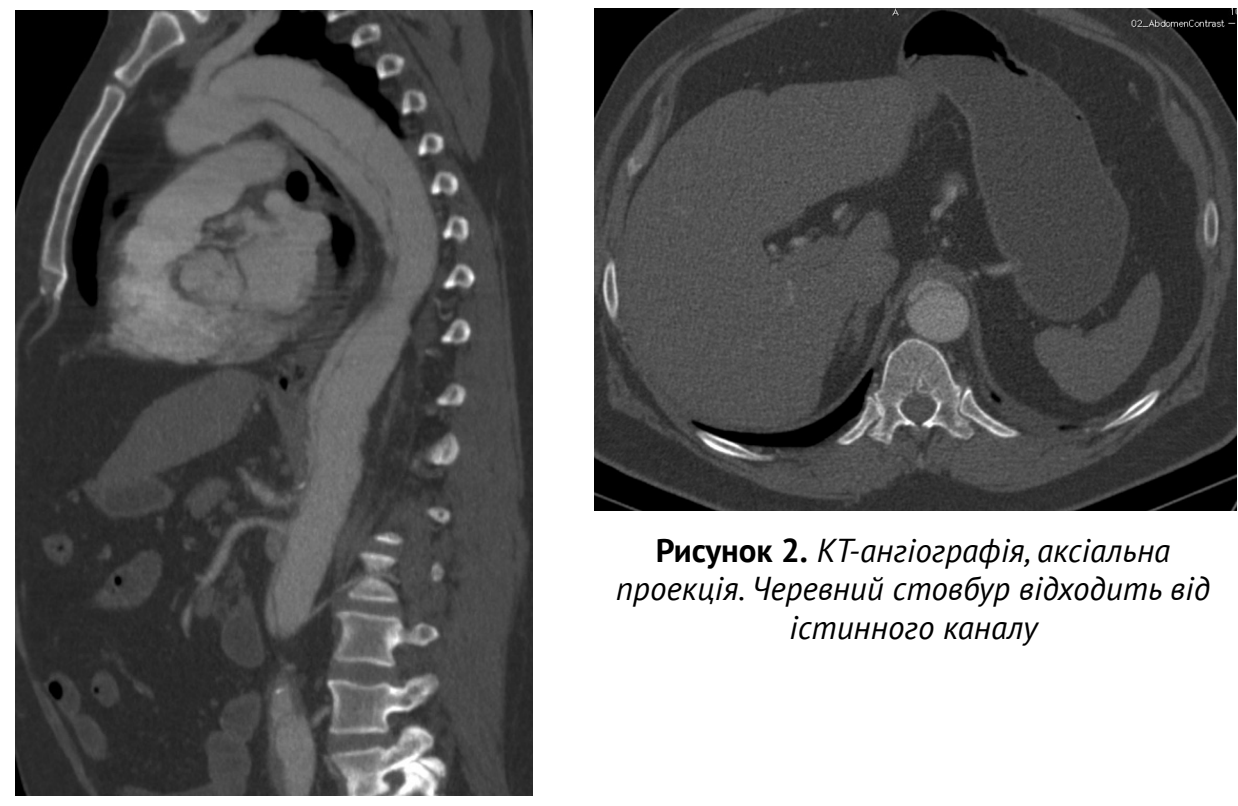

Рисунок 2. КТ-ангіографія, аксіальна проекція. Черевний стовбур відходить від істинного каналу

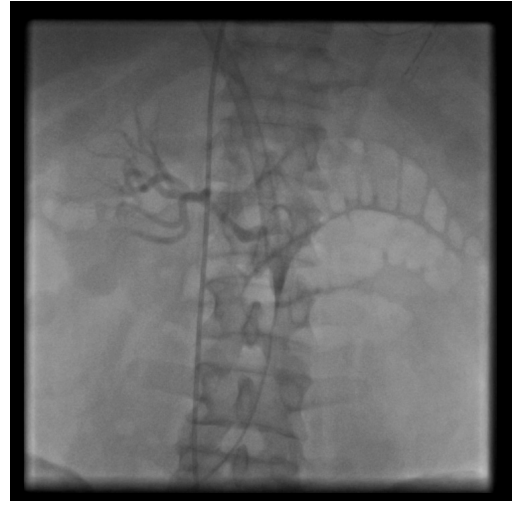

Рисунок 3. Ангіографія істинного каналу до ендопротезування
Рисунок 1. КТ-ангіографія, сагітальна проекція. Розшарування аорти тunу В. Динамічна компресія істинного каналу та вісцеральних судин роскопію з ревізією кишечника. Кишечник виявився життєздатним, нормальна перистальтика відновилася лише через місяць після втручання.

Обговорення. Синдром мальперфузії - це найбільш грізне ускладнення гострого розшарування аорти. Мальперфузією називають різке зниження кровотоку в органи. Зниження кровотоку призводить, у свою чергу, до гіпоксії, ішемії та порушення функції органа. Синдром мальперфузії є незалежним фактором ризику смерті при розшаруванні аорти: внутрішньогоспітальна летальність, згідно з даними міжнародного реєстру IRAD, становить $31 \%$ [1, 6, 7]. Синдром мальперфузії може проявлятися клінічно (різкий біль у животі, пронос, блювання - при вісцеральній мальперфузії, анурія - при мальперфузії нирок, біль у ногах, інсульт або деменція при мальперфузії сонних артерій) або лабораторно (підвищення рівня креатиніну при мальперфузії нирок або підвищення лактату - при мальперфузії кишечника). Вкрай рідко відзначається ізольована мальперфузія одного органа. Як правило, мальперфузія кишечника комбінується з мальперфузією нижніх кінцівок або нирок.

Комп’ютерна томографія є золотим стандартом у діагностиці синдрому мальперфузіі. Також комп'ютерна томографія з контрастуванням є одним зі стандартних методів діагностики панкреатиту, дає найбільш точну оцінку ступеня важкості гострого панкреатиту і мала б бути виконана з моменту появи симптомів у нашо-

\section{Рисунок 4.}

Ангіографія істинного каналу після ендопротезування

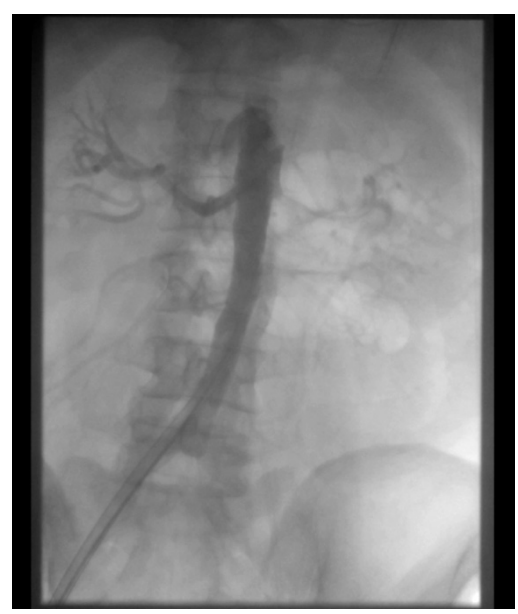

го пацієнта [3]. Вірогідність синдрому мальперфузії у пацієнтів із гострим розшаруванням становить $21 \%$ (IRAD), у тому числі мезентеріальна ішемія трапляється із частотою 5,3\%, ниркова недостатність - 13,5\%, ішемія нижніх кінцівок - 7,1\%. При цьому серед пацієнтів міжнародного реєстру не зареєстровано жодного випадку гострого панкреатиту на фоні мальперфузії truncus celiacus i селезінкової артерії. Однак зареєстровано окремі клінічні випадки гострого ішемічного панкреатиту на фоні мальперфузії черевного стовбура при розшаруванні аорти [2]. Патофізіологія синдрому мальперфузії при розшаруванні аорти може бути динамічною (коли внаслідок росту тиску в хибному каналі стискується істинний канал аорти, а латка інтими перекриває вхід до судини) або статичною (коли розшарування продовжується безпосередньо на судину, а в хибному каналі формується тромб) (рисунок 5). Досить часто спостерігається змішаний тип мальперфузіі.

Згідно з даними IRAD, статична мальперфузія відзначається у $80 \%$ пацієнтів, і лише у 20\% мальперфузія є динамічною. Динамічна мальперфузія є досить підступною. Ïї не завжди видно на комп’ютерній томограмі, 

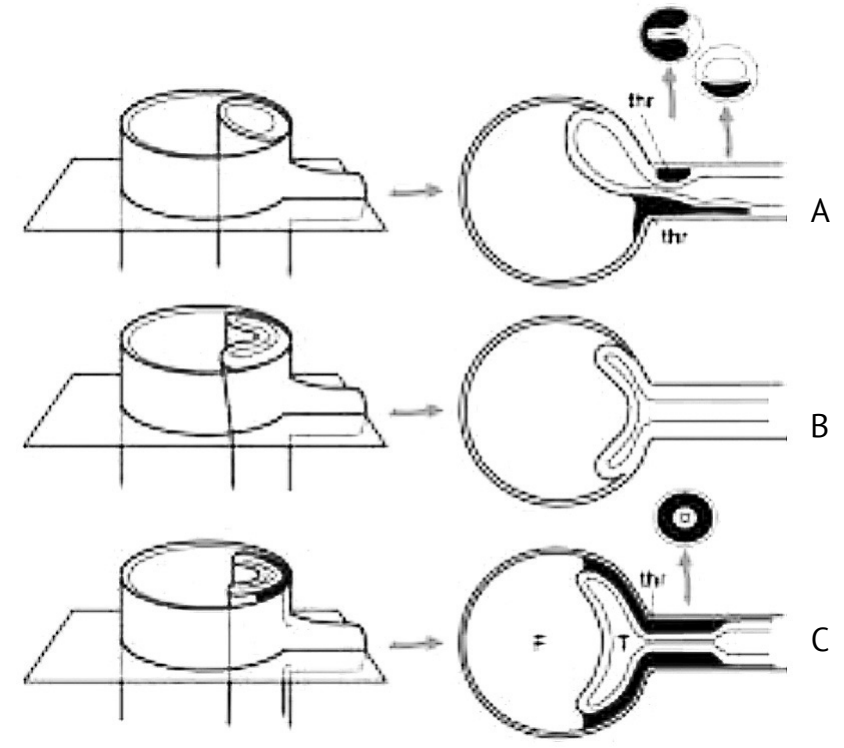

Рисунок 5. Види синдрому мальперфузії: A - статична мальперфузія; $B$ - динамічна мальперфузія; $C$ - змішана мальперфузія

оскільки латка інтими може коливалися від однієї до іншої стінки аорти. Так само симптоми можуть проявлятися від незначних (наприклад, проносу) до різко виражених (наприклад, різкого болю в животі), від раптового полегшення до такого самого раптового погіршення.

Лікування при ускладненому синдромі мальперфузії при гострому розшаруванні аорти типу В є невідкладним і дозволяє знизити летальність, згідно з даними IRAD, з 80\% за відсутності лікування або з 60\% при лише медикаментозному лікуванні до 25\% при хірургічному або ендоваскулярному лікуванні. На сьогодні більшість центрів віддають перевагу ендоваскулярному лікуванню через відсутність необхідності перетискання аорти під час штучного кровообігу, переливання препаратів крові та меншу тривалість процедури, що є вкрай важливим при синдромі мальперфузії. Метою втручання при динамічній обструкції в ідеалі є перекриття ініціального розриву інтими та зниження тиску в хибному каналі. Ідеальним методом для цього $є$ ендопротезування аорти, що було виконано пацієнту. За неможливості перекриття ініціального розриву, при змішаному виді мальперфузії, при наявності інтрамуральної гематоми в зоні посадки ендопротеза часом виконують балонну фенестрацію інтими трохи вище відходження вісцеральних судин та стентування фенестрації з метою вирівнювання тиску в істинному і хибному каналах та покращення кровотоку по вісцеральним судинам (рисунок 6).

При статичній мальперфузії ендопротезування аорти або створення фенестрації доповнюють стентуванням судини або шунтуванням вісцеральних судин.

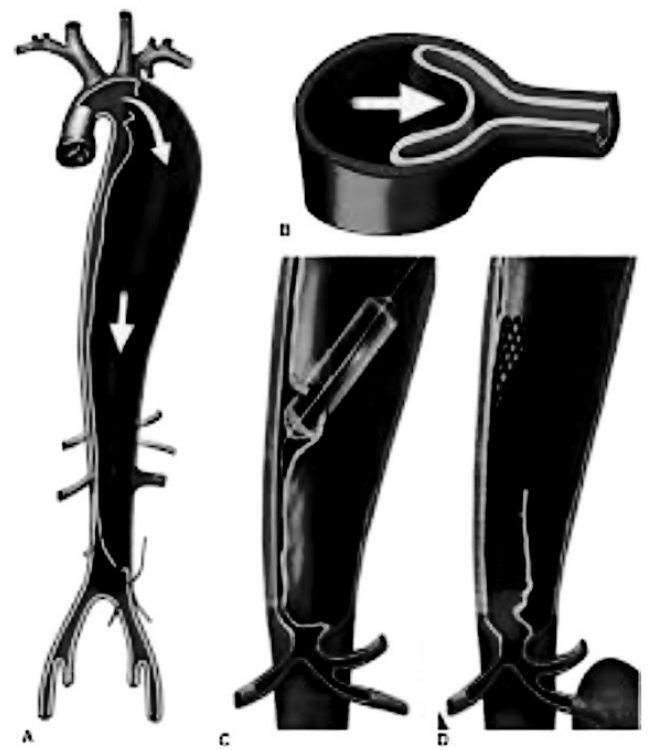

Рисунок 6. Балонна фенестрація інтими та стентування фенестраціі

Проте, незважаючи на досягнення сучасної медицини в галузі лікування гострого аортального синдрому, летальність при гострому розшаруванні аорти, ускладненому синдромом мальперфузії, незважаючи на виконану хірургічно ендоваскулярну або гібридну корекцію, залишається високою і сягає 25\%. Критичним часом для допомоги хворим із синдромом мальперфузії є 6-12 годин для кишечника, 24 години для нирок, 12-18 годин для підшлункової залози, 6-10 годин для печінки [4]. Але оскільки симптоми розшарування аорти, ускладненого синдромом мальперфузії. не $є$ специфічними, у більшості пацієнтів встановити діагноз до критичного часу ішемії органа не вдається. Крім того, дані IRAD вказують, що у $40 \%$ пацієнтів із мезентеріальною ішемією не було болю в животі, $20 \%$ пацієнтів не мають ознак мальперфузії за даними КТ $[1,6,7]$. Часто мальперфузія вісцеральних гілок аорти недооцінюється за даними КТ, особливо у випадку динамічної мальперфузії, коли перфузія органа залежить від динамічного показника - різниці тиску в істинному та хибному каналі. Має значення і час проведення $\mathrm{KT}$, оскільки розшарування може прогресувати і заходити в одну з вісцеральних судин.

Запорукою успіху в лікуванні синдрому мальперфузії є: 1) вчасне встановлення діагнозу; 2) вчасне відновлення кровотоку; 3) лапароскопічна ревізія кишечника в разі найменших сумнівів у його життєздатності; 4) активне спостереження. Загалом від $14 \%$ до $53 \%$ пацієнтів із гострою мезентеріальною ішемією потребують резекції кишечника [1]. Деякі автори вважають виправданим проведення повторної лапароскопічної 
оцінки кишечника після резекції в разі найменшої підозри на некроз. У нашого пацієнта з моменту встановлення діагнозу минуло два тижні: КТ-ангіографія показала наявність динамічної мальперфузії, а дані лапароскопії, незважаючи на персистування симптоматики після відновлення кровотоку по вісцеральним судинам, показали відсутність некрозу кишечника. Найбільш імовірно, внаслідок динамічної обструкції істинного каналу та постійної зміни тиску в істинному та хибному каналах не призвели до фатальних змін у кишечнику. Також неймовірним є той факт, що в нашого пацієнта на ішемічні зміни першою відреагувала підшлункова залоза, менш чутлива до ішемії, ніж кишечник.

Висновки. Гостре розшарування аорти типу В із синдромом мальперфузії може бути маскою багатьох захворювань. У незрозумілих ситуаціях комп'ютерна томографія є запорукою успіху в діагностиці захворювання.

\section{Список використаних джерел}

1. Federik HWet al. Acute type B aortic dissection complicated by visceral ischemia. The $\mathrm{J}$ of Thorac and Cardiovasc Surg. 2015 April; 149(4):1-6.

2. Masaki Hamamoto. Acute ischemic pancreatitis associated with acute type B aortic dissection. Ann Vasc Dis. 2012;5(3):385-388.

3. Dr Daniel J Bell et al. Acute pancreatitis.- Radiopaedia. org

4. Acceptable ischemic times/Nebraska Organ Recovery. www.nedonation.org

5. Char DJ. Surgical intervention for acute intestinal ischemia: experience in a community teaching hospital. Vasc Endovasc Surg, 2003;37(4):245-52.

6. Arturo Evangelista. Insights form the International registry of Acute aortic dissection. Global Cardiol Sci Pract. 2016;31 Mar;1:e201608.

7. Hagan P.G. The International registry of Acute Aortic Dissection (IRAD): new insights into an old disease. JAMA. 2000 Feb 16;283(7):897-903.

\title{
Visceral malperfusion syndrome masks in acute type B aortic dissection
}

\author{
Yashchuk N., Ditkivskyy I., Cherpak B., Kravchenko V.
}

National M. M. Amosov Institute of Cardiovascular Surgery National Academy of Medical Sciences of Ukraine, Kyiv, Ukraine

Acute aortic dissection (AAD) is a life-threatening condition associated with high morbidity and mortality rates, and it remains a challenge to diagnose and treat. Visceral malperfusion syndrome affects almost $21 \%$ of the patients with acute type B aortic dissection. Moreover, according to the IRAD (International Registry of Aortic Dissection) data, it is an independent risk factor for hospital mortality and accounts for $30.8 \%$. A wide variability of symptoms causes delay in diagnosing in $28 \%$ of the patients with abdominal pain thus explaining a high mortality rate.

Case description. This manuscript presents a case of successful treatment of dynamic visceral malperfusion in a man presenting with the symptoms of acute pancreatitis and a two-week delay in diagnosing. The patient had an entry tear covered with a thoracic endovascular stent graft (TEVAR) following visceral flow restoration. Due to the persistent abdominal pain despite successful repair, the patient underwent diagnostic laparoscopy in order to assess the bowel viability. Normal bowel passage was restored one month after the TEVAR procedure.

Discussion. Visceral ischemia is a life-threatening complication of acute type B aortic dissection. Presentation of visceral ischemia can be challenging, which may lead to crucial delays in diagnosis and treatment. The mechanism of compromised branch vessels can be both static and dynamic. In cases of suspicion of ABAD with visceral ischemia, urgent additional imaging, preferably CTA should follow. After CTA however, doubts may remain regarding visceral malperfusion, as no involvement of visceral vessels is seen in $20 \%$ of these patients. These patients usually have dynamic obstruction by prolapse of the dissection flap into the vessel ostium. Urgent restoration of the visceral organ perfusion should be the first step of management. The management of dynamic obstruction involves different approaches: from TEVAR with an entry tear to the false lumen coverage by TEVAR to intimal flap fenestration via the funnel technique. After successful restoration of visceral perfusion, patients should be monitored closely, and the bowel should be examined when there is a doubt regarding its viability. Generally, bowel resection may be needed in 14 to $53 \%$ of the patients presenting with acute mesenterial ischemia.

The International Registry of Acute Aortic Dissection (IRAD) database recognizes malperfusion in $21 \%$ of the patients with Stanford type B aortic dissection. However, acute pancreatitis is not described as an ischemic complication of acute aortic dissection in the IRAD. As the precise aetiology of pancreatitis following aortic dissection continues to be elucidated, what remains is the diagnostic challenge of efficiently differentiating between the clinical manifestations of aortic dissection and other aetiologies of acute abdominal pain such as acute cardiac ischemia, pancreatitis, or intestinal obstruction. Acute pancreatitis presenting as acute aortic dissection is a rare entity with less than ten well-documented cases reported so far. It is hypothesized that the pancreas can be susceptible to hypoperfusion as seen in cardiopulmonary bypass surgery. We present a case misdiagnosed as acute pancreatitis only based on the clinical symptoms and later correctly diagnosed as an aortic dissection when the symptoms did not improve.

Conclusion. Acute aortic dissection may be a mask of different diseases. In not explainable and not curable situations, CTA plays an important role in diagnosis and management of the disease.

Keywords: visceral malperfusion syndrome, acute aortic dissection, acute pancreatitis. 